\title{
Pengaruh Model Pembelajaran Assure Bernuansa Lingkungan Berbantuan Media Audiovisual terhadap Hasil Belajar IPS ditinjau dari Minat Outdoor Siswa
}

\author{
Made Ayu Pransisca1* ${ }^{*}$, A.A.I.N Marhaeni² ${ }^{2}$ I Wayan Lasmawan ${ }^{3}$ \\ 1,2,3 Program Studi Pendidikan Dasar, Program Pascasarjana Universitas Pendidikan Ganesha Singaraja, Indonesia
}

\section{ARTICLEIN \\ $\mathrm{FO}$ \\ Article history: \\ Received 17 \\ November 2017 \\ Received in revised \\ form \\ 12 Desember 2017 \\ Accepted 15 Januari \\ 2018 \\ Available online 20 \\ Februari 2018

Kata Kunci:
model Pembelajaran
Assure, media
Audiovisual, minat
Outdoor, hasil
Belajar.
Keywords:

$\frac{\text { A B S T R A K }}{\text { Penelitian ini bertujuan untuk menyelidiki pengaruh model }}$ pembelajaran assure bernuansa lingkungan berbantuan media audiovisual terhadap hasil belajar IPS ditinjau dari minat outdoor siswa kelas V SDN Gugus 1 Masbagik Utara Lombok Timur. Penelitian ini menggunakan pendekatan eksperimen semu dengan rancangan post test two group faktorial design. Populasi dalam penelitian ini sebanyak 143 orang siswa. Sampel penelitian ini berjumlah 76 orang siswa ditentukan dengan teknik random sampling. Data minat outdoor siswa dikumpulkan dengan kuisioner dan data hasil belajar IPS dikumpulkan dengan tes. Data dianalisis menggunakan Anava AB berbantuan SPSS 16.00 for windows. Hasil penelitian menunjukkan bahwa: 1) Terdapat perbedaan yang signifikan hasil belajar IPS antara siswa yang mengikuti pembelajaran dengan model pembelajaran Assure bernuansa lingkungan berbantuan media audiovisual dan siswa yang mengikuti pembelajaran konvensional. 2) Terdapat pengaruh interaksi yang signifikan antara model pembelajaran Assure bernuansa lingkungan berbantuan media audiovisual dan minat outdoor terhadap hasil belajar IPS siswa, 3) Pada siswa yang memiliki minat outdoor tinggi, terdapat perbedaan signifikan hasil belajar IPS antara siswa yang mengikuti pembelajaran dengan model pembelajaran Assure bernuansa lingkungan berbantuan media audiovisual dan siswa yang mengikuti pembelajaran konvensional, 4) Pada siswa yang memiliki minat outdoor rendah, tidak terdapat perbedaan signifikan hasil belajar antara siswa yang mengikuti pembelajaran dengan model pembelajaran Assure bernuansa lingkungan berbantuan media audiovisual dan siswa yang mengikuti pembelajaran konvensional.

A B S T R A C T

The purpose of this research was to explore The Effects of Assure Learning Model Audiovisual Media Assisted on IPS Learning Outcomes Viewed from Outdoor Interest of V-Class Students of SDN Gugus 1 North Masbagik, East Lombok.This research used quasi-experimental approach with the post test two group factorial design. The population of this research was 143 students. The sample of this research amounted to 76 students determined by random sampling technique. The data of students' outdoor interest was collected by using questionnaire and the data of IPS learning result was collected by using test. The data were analyzed using SABS assisted Anava AB 16.00 for windows. The results showed that: 1) There was a significant difference of the IPS learning outcomes between the students who followed the learning model with Assure model of audiovisual media-assisted environment and the students who followed the conventional learning ; 2) There was a significant interaction effect between Assure learning model nuanced audiovisual media environment and outdoor interest toward student's learning result of IPS , 3). For the students with high outdoor interest, there was significant differences in IPS learning outcomes between the students who followedthe learning model with Assure learning nuanced audiovisual media environment and students who followed conventional learning, 4). For the students with low outdoor interest, there was no significant difference in learning outcomes between the students who followed the learning model with Assure learning nuanced audiovisual media environment and the students who followed conventional learning

Copyright (C) Universitas Pendidikan Ganesha. All rights reserved.

\footnotetext{
* Corresponding author.

E-mail addresses: made@yahoo.com (Made Ayu Pransisca)
} 


\section{Pendahuluan}

Pendidikan merupakan usaha sadar dan terencana untuk mewujudkan suasana belajar dan proses pembelajaran agar siswa secara aktif mengembangkan dan meningkatkan potensi yang dimilikinya. Setiap manusia dilahirkan mempunyai potensi dalam dirinya, oleh sebab itu perlu dilakukan suatu usaha yang dapat membantu manusia mengenali potensi dirinya dan mengembangkan bakatnya. Pernyataan ini didukung oleh Ki Hajar Dewantara (dalam Dantes, 2014) yang menyatakan bahwa "pendidikan adalah memanusiakan manusia.

Menurut Ratumanan (dalam Mitha dkk, 2014) menyatakan bahwa "pembelajaran merupakan suatu kondisi di mana guru membantu siswa untuk membangun pengetahuan dan kemampuannya sendiri melalui konsep internalisasi sehingga pengetahuan itu dapat terkontruksi kembali”. Untuk menciptakan suatu pembelajaran yang berorientasi pada keterlibatan dan aktivitas siswa, diperlukan kemampuan guru dalam mendesain, mengimplementasikan, dan menyeluruh (holistik) untuk dapat mendorong siswa mengembangkan kompetensi yang dipelajari dengan kemampuannya sendiri. Selain itu, pemanfaatan media yang tepat dan menarik dapat membantu dalam menciptakan situasi pembelajaran yang bersifat interaktif dengan melibatkan aktivitas siswa di dalamnya. Salah satu inovasi dalam mendesain pembelajaran yang bisa dilakukan adalah dengan penerapan model pembelajaran Assure bernuansa lingkungan berbantuan media audiovisual ditinjau dari minat outdoor. Model ASSURE adalah salah satu model yang dapat menuntun pembelajar secara sistematis untuk merencanakan proses pembelajaran secara efektif (Wibowo, 2014). Model pembelajaran Assure adalah sebuah model pembelajaran yang bersifat praktis dan mudah digunakan serta berisi langkah-langkah yang sistematik dan sistemik yang meliputi: analyze learner characteristics (menganalisis karakteristik siswa); state performance objectives (menetapkan tujuan pembelajaran); select methods, media and materials (memilih metode, media dan bahan pelajaran); utilize materials (memanfaatkan bahan dan media pembelajaran); requires learner participation (mengaktifkan keterlibatan siswa); evaluation and revision (evaluasi dan revisi) (Jayanti dan Putra, 2014).

Pembelajaran model ASSURE diharapkan dapat meningkatkan pemahaman siswa serta melibatkan siswa secara langsung dalam proses pembelajaran dan memotivasi siswa. Model ASSURE merupakan suatu model pembelajaran yang lebih berorientasi pada pemanfaatan media dan teknologi dalam menciptakan proses dan aktivitas pembelajaran yang diinginkan.

Lingkungan adalah keseluruhan fenomena (peristiwa, situasi atau kondisi) fisik atau alam atau sosial yang mempengaruhi atau dipengaruhi perkembangan individu, Yusuf dan Sugandhi (dalam Ardiani dkk, 2014). Lingkungan yang berada disekitar kita dapat dijadikan sebagai sumber belajar. Lingkungan meliputi: Masyarakat disekeliling sekolah; Lingkungan fisik disekitar sekolah, bahan-bahan yang tersisa atau tidak dipakai, bahan-bahan bekas dan bila diolah dapat dimanfaatkan sebagai sumber atau alat bantu dalam belajar, serta peristiwa alam dan peristiwa yang terjadi dalam masyarakat (Aptisoma, 2009).

Zaman yang maju akan ilmu pengetahuan dan teknologi, khususnya teknologi informasi, sangat berpengaruh terhadap penyusunan dan implementasi strategi pembelajaran. Melalui kemajuan tersebut para guru dapat menggunakan berbagai media sesuai dengan kebutuhan dan tujuan pembelajaran. "Melalui penggunaan media komunikasi seperti media pembelajaran audiovisual, yang tidak hanya dapat mempermudah dan mengefektifkan proses pembelajaran, akan tetapi juga dapat membuat proses pembelajaran lebih menarik" Sanjaya (dalam Utomo dan Poedjiastoeti, 2014).

Media audiovisual merupakan media perantara atau penggunaan materi melalui pandangan dan pendengaran sehingga membangun kondisi yang dapat membuat siswa menjadi lebih aktif dalam belajar sebagaimana dikatakan oleh Mitha dkk (2014). Pembelajaran yang baik dan menyenangkan tidak hanya terjadi di dalam kelas di luar kelas pun kita bisa menciptkan kondisi belajar yang menyenangkan salah satunya dengan pembelajaraan Outdoor, siswa akan lebih aktif untuk belajar dan pembelajaran dapat bermakna bagi siswa. Dalam penelitian ini minat Outdoor didefinisikan sebagai suatu kecenderungan atau keinginan hati yang tinggi untuk memilih sesuatu kegiatan yang berhubungan dengan alam seperti binatang, tumbuhan dan benda-benda di sekitar kita berdasarkan situasi yang dihubungkan dengan keinginan-keinginan atau kebutuhan-kebutuhannya sendiri menurut Winkel (dalam Dewi dkk, 2014). Oleh karena itu, apa yang dilihat seseorang sudah tentu akan membangkitkan minatnya sejauh apa yang dilihat mempunyai hubungan dengan kepentingannya sendiri. Dalam minat outdoor ini terdapat tiga indikator yaitu: 1) ketertarikan; 2) perhatian; 3) dan ketersediaan meluangkan waktu.

Saat ini masih sangat sulit bagi guru mengetahui prilaku dalam proses pembelajaran dan hasil belajar siswa khususnya dalam pelajaran IPS. Ilmu Pengetahuan Sosial (IPS) sebagai salah satu bidang studi yang mempelajari tentang interaksi sosial manusia dalam masyarakat dapat menjadi sarana untuk memperoleh dan mengembangkan pengetahuan, keterampilan, sikap, dan kepekaan untuk menghadapi hidup bermasyarakat dengan tantangan - tantangannya (Sari, 2014). Pembelajaran IPS SD bertujuan 
untuk membekali siswa dalam pengetahuan dan kemampuan tentang kehidupan bermasyarakat, mulai dari berkomunikasi, berinteraksi, bekerjasama hingga berkompetensi. Selain itu, pembelajaran IPS diharapkan dapat membentuk siswa yang sadar akan nilai-nilai sosial dan kemanusiaan. Mata pelajaran IPS di SD dapat menjadi wadah pembelajaran anak menuju pembentukan warga negara yang baik, yaitu warga negara yang memiliki kemampuan dan keterampilan yang berguna bagi diri dalam hidup seharihari dan warga negara yang bangga sebagai bangsa Indonesia dan cinta tanah air. Usaha yang dapat dilakukan untuk mencapai tujuan tersebut adalah memberi kesempatan pengalaman belajar kepada peserta didik. Peserta didik diasah kepekaan sosialnya, mengetahui materi IPS secara kontekstual dan bukan sekedar tekstual (Likhah, 2014). Dengan demikian, hendaknya dalam pembelajaran IPS, siswa dibawa langsung ke dalam lingkungan sosial dan kehidupan bermasyarakat. Fakta dilapangan membuktikan bahwa kualitas pendidikan maupun kualitas proses pembelajaran IPS masih tidak sesuai dengan harapan pemerintah, salah satunya di SDN kelas V gugus 1 Masbagik Utara. Pada pembelajaran IPS sering kali hasil belajar siswa masih rendah, masih banyak siswa yang nilainya di bawah Kriteria Ketuntasan Minimal (KKM), mengenai rendahnya hasil belajar IPS berdasarkan data hasil observasi dan wawancara yang peneliti lakukan, dapat diidentifikasi bahwa terdapat beberapa gejala/faktor yang menyebabkan hasil belajar IPS siswa, yaitu (1) peserta didik kurang bisa memberikan tanggapan terhadap hasil diskusi. (2) masih banyak guru yang menerapkan model pembelajaran konvensional. (3) model dan penggunaan media yang digunakan guru masih belum memperhatikan pemahaman siswa. (4) siswa jarang dilatih untuk memecahkan masalah. (5) penilaian masih terfokus pada penilain kognitif saja. Berdasarkan paparan di atas membuktikan bahwa masih rendahnya hasil belajar IPS siswa.

Menyadari adanya permasalahan yang ditemukan di Sekolah Dasar Gugus I maka salah satu upaya/solusi yang dapat ditawarkan untuk meningkatkan hasil belajar IPS siswa adalah dengan menerapkan kegiatan dan bahan pembelajaran yang dapat menciptakan pembelajaran yang efektif. Pembelajaran tidak hanya fokus pada pemberian kemampuan pengetahuan teoritis, tetapi bagaimana agar pengalaman belajar peserta didik senantiasa terkait dengan permasalahan aktual yang terjadi di lingkungannya (Rusman, 2011). Kegiatan dan bahan pembelajaran harus sesuai dengan lingkungan peserta didik serta terkait pengalamannya dari interaksi dengan lingkungan, sehingga pembelajaran harus berisi bahan dan kegiatan pembelajaran yang memungkinkan peserta didik belajar untukmengeksplorasi lingkungannya secara aktif. Media pembelajaran yang berbantuan pada lingkungan dapat diterapkan dalam pembelajaran IPS. Pembelajaran yang dapat memungkinkan siswa untuk belajar menyenangkan dan inovatif adalah Model pembelajaran Assure merupakan model desain pembelajaran yang bersifat praktis dan mudah untuk digunakan. Model ini dapat diaplikasikan untuk mendesain aktivitas pembelajaran, baik yang bersifat individual maupun kelompok. Model pembelajaran ini lebih berorientasi kepada pemanfaatan media dan teknologi dalam menciptakan proses dan aktivitas pembelajaran yang diinginkan. Pemanfaatan model pembelajaran Assure perlu dilakukan tahap demi tahap (sistematik) dan menyeluruh (holistik) agar dapat memberikan hasil yang optimal yaitu terciptanya pembelajaran yang sukses. (Pribadi, 2011). Beranjak dari paradigma tersebut, dilaksanakan sebuah penelitian dengan menggunakan model pembelajaran Assure bernuansa lingkungan berbantuan media audiovisual ditinjau dari minat outdoor, maka peneliti memasukkan ide ini ke dalam penelitian yang berjudul "Pengaruh Model Pembelajaran Assure Bernuansa Lingkungan Berbantuan Media Audiovisual Terhadap Hasil Belajar IPS Ditinjau dari Minat Outdoor Siswa Kelas V SDN Gugus 1 Masbagik Utara Lombok Timur Tahun Pelajaran 2017/2018".

Mengingat masalah tersebut sangat penting, maka dilakukan penelitian dengan tujuan: 1) Untuk menganalisis dan mendeskripsikan perbedaan hasil belajar IPS antara siswa yang mengikuti model pembelajaran Assure bernuansa lingkungan berbantuan media audiovisual dengan siswa yang mengikuti model pembelajaran konvensional, 2) Untuk menganalisis dan mendeskripsikan pengaruh interaksi antara implementasi model pembelajaran dengan minat Outdoor terhadap hasil belajar IPS siswa kelas V SDN Gugus 1 Masbagik Utara, 3) Untuk menganalisis dan mendeskripsikan siswa yang memiliki minat Outdoor tinggi, apakah terdapat perbedaan hasil belajar IPS antara siswa yang mengikuti model pembelajaran Assure bernuansa lingkungan berbantuan media audiovisual dengan siswa yang mengikuti model pembelajaran konvensional, 4)Untuk menganalisis dan mendeskripsikan siswa yang memiliki minat Outdoor rendah, apakah terdapat perbedaan hasil belajar IPS antara siswa yang mengikuti model pembelajaran Assure bernuansa lingkungan berbantuan media audiovisual dengan siswa yang mengikuti model pembelajaran konvensional.

\section{Metode}

Penelitian ini dilaksanakan di Gugus I Tahun Pelajaran 2017/2018. Jenis penelitian ini dikategorikan penelitian faktorial $2 \times 2$. Desain penelitian adalah faktorial $2 \times 2$ dengan menggunakan 
kelompok eksperimen (model pembelajaran Assure bernuansa lingkungan berbantuan media audiovisual ditinjau dari minat outdoor) dan kelompok kontrol (model pembelajaran konvesional). Populasi dalam penelitian ini adalah seluruh siswa kelas V Gugus I Kecamatan Lombok Timur Kabupaten Masbagik.Teknik pengambilan sampel dengan random sampling. Hasil pemilihan sampel menetapkan bahwa siswa SDN 1 Masbagik Utara dan SDN 4 Masbagik Utara yang secara keseluruhan berjumlah 61 siswa terpilih menjadi sampel untuk kelas eksperimen. Sedangkan, SDN 2 Masbagik Utara dan SDN 9 Masbagik Utara yang secara keseluruhan berjumlah 56 siswa terpilih menjadi sampel untuk kelas kontrol.Variabel bebas dalam penelitian ini berupa model pembelajaran Assure bernuansa lingkungan berbantuan media audiovisual dan model pembelajaran konvensional, variabel terikatnya berupa hasil belajar IPS sedangkan variabel moderator adalah minat outdoor. Teknik pengumpulan data yang digunakan dalam penelitian ini adalah teknik tes dan non-tes. Teknik tes digunakan untuk mengambil data hasil belajar IPS, dalam penelitian ini tes yang digunakan adalah tes objektif dengan bentuk pilihan ganda dan Teknik non-tes dalam penelitian ini dengan menggunakan lembar kuesioner minat outdoor siswa dengan modifikasi dari skala Likert. Analisis data yang digunakan pada penelitian ini analisis statistik deskriptif, yang artinya bahwa data dianalisis dengan menghitung nilai rata-rata, modus, median, standar deviasi, varian, skor maksimum, dan skor minimum. Dalam penelitian ini data disajikan dalam bentuk grafik histogram. Teknik yang digunakan untuk menganalisis data guna menguji hipotesis penelitian adalah ANAVA AB. Sebelum dilakukan analisis data, maka dilakukan uji normalitas sebaran data dengan menggunakan uji Kolmogorov-smirnov, uji homogenitas varians dengan uji Levene's, dan uji korelasi antar variabel terikat (kolinieritas) dengan menggunakan product moment.

\section{Hasil dan Pembahasan}

Perbedaan Hasil Belajar IPS Antara Siswa Yang Mengikuti Pembelajaran Dengan Model Assure Bernuansa Lingkungan Berbantuan Media Audiovisual Dengan Siswa Yang Mengikuti Pembelajaran Dengan Pendekatan Konvensional. Berdasarkan hasil temuan dalam penelitian ini, memiliki nilai $\mathrm{F}_{\mathrm{A}}$ hitung $=14,489$ dengan $\mathrm{p}<0,05$. Dengan demikian, hipotesis nol $\left(\mathrm{H}_{0}\right)$ yang menyatakan tidak terdapat perbedaan hasil belajar IPS antara siswa yang mengikuti pembelajaran dengan model Assure bernuansa lingkungan berbantuan media audiovisual dengan siswa yang mengikuti pembelajaran dengan pendekatan konvensional, "ditolak". Dengan perkataan lain dapat ditarik kesimpulan bahwa terdapat perbedaan hasil belajar IPS antara siswa yang mengikuti pembelajaran dengan model Assure bernuansa lingkungan berbantuan media audiovisual dengan siswa yang mengikuti pembelajaran dengan pendekatan konvensional. Penelitian lain yang mendukung temuan ini adalah Muammar dkk (2015) yang menyatakan bahwa, terdapat pengaruh model pembelajaran terhadap hasil belajar IPA, terkait model pembelajaran, model Assure lebih baik dari model konvensional. Hal ini dapat dilihat bahwa nilai rata-rata model Assure lebih tinggi dari model konvensional.

Hal diatas dikuatkan oleh ciri dengan model Pembelajaran Assure, menurut Pribadi (2011) model Assure adalah pembelajaran yang berorientasi kepada pemanfaatan media dan teknologi dalam menciptakan proses dan aktivitas pembelajaran yang diinginkan. Pemanfaatan model desain pembelajaran Assure perlu dilakukan tahap demi tahap (sistematik) dan menyeluruh (holistik) agar dapat memberikan hasil yang optimal yaitu terciptanya pembelajaran sukses. Belajar IPS tidak hanya sekadar belajar tentang konsep-konsep tetapi belajar secara bermakna. Bermakna dalam hal ini siswa tahu tujuan mereka belajar IPS. Siswa belajar bermakna jika materi dalam pembelajarannya dikaitkan dengan kehidupan nyata yang dekat dengan keseharian siswa. Salah satu tujuan belajar IPS adalah untuk memberikan pengetahuan yang merupakan kemampuan untuk melihat kembali atau mengenal kembali yang telah dialami dalam bentuk yang sama atau dialami sebelumnya (Lasmawan, 2010). Berdasarkan uraian di atas terlihat adanya kesesuaian antara belajar IPS dengan pembelajaran dengan model Assure. Di satu sisi proses pembelajaran IPS harus dapat menghubungkan antara konsep sosial dengan situasi dunia nyata yang pernah dialami ataupun yang pernah dipikirkan siswa.

Pengaruh Interaksi Antara Implementasi Model Pembelajaran Dengan Minat Outdoor Terhadap Hasil Belajar IPS. Berdasarkan hasil temuan dalam penelitian ini, Tolak Ho jika $F_{A B h i t u n g} \geq F_{A B t a b e l}$ pada taraf signifikan $\alpha=0,05$, sebaliknya terima Ho jika $F_{A B h i t u n g} \leq F_{A B t a b e l}$ pada taraf signifikan $\alpha=0,05$. Berdasarkan hasil analisis Anava dua jalur diperoleh nilai $F_{h i t u n g}=36,202$ dengan $p<0,05$. Dengan demikian hipotesis nol (Ho) yang menyatakan tidak terdapat pengaruh interaksi antara implementasi model pembelajaran dengan minat outdoor terhadap hasil belajar IPS, “ditolak”. Dengan demikian, dapat disimpulkan bahwa terdapat pengaruh interaksi antara implementasi model pembelajaran dengan minat outdoor terhadap hasil belajar IPS.

Temuan penelitian ini didukung oleh penelitian Rahmawati, Endah Rita dan Atip Nurwahyuni (2017) yang menyatakan Adanya pengaruh interaksi penggunan pembelajaran Outdoor Learning pada 
Model Discovery Learning terhadap hasil belajar siswa dibuktikan dengan nilai rata-rata posttest kelas eksperimen 84,0 kelas kontrol dengan rata-rata 69,4. Pembahasan terhadap hasil penelitian di atas beranjak dari kesesuaian antara minat outdoor dengan model pembelajaran yang harus diberikan untuk mencapai hasil belajar yang maksimal. Menurut Dewi, Suarni dan Widiartini (2014) minat outdoor merupakan ketertarikan siswa terhadapat lingkungan di sekitarnya. Berdasarkan karakteristik tersebut, model pembelajaran yang sesuai dengan karakteristik siswa adalah model Assure bernuansa lingkungan berbantuan media audiovisual yang memberikan siswa untuk menetapkan pengalaman belajar yang dapat membantu siswa dalam mencapai kompetensi yang diinginkan. Berdasarkan hasil penelitian di atas, dapat disimpulkan bahwa model pembelajaran dengan minat outdoor sangat efektif diterapkan untuk meningkatkan hasil belajar dalam pembelajaran IPS siswa.

Perbedaan Hasil Belajar IPS Antara Siswa Yang Mengikuti Model Pembelajaran Assure Dengan Siswa Yang Mengikuti Model Pembelajaran Konvensional Pada Minat Outdoor Tinggi. Berdasarkan hasil temuan dalam penelitian ini, perhitungan didapat $t_{\text {hitung }}$ sebesar 6,934 sedangkan $t_{\text {tabel }}$ pada taraf signifikansi $\alpha=0,05$ sebesar 1,980 . Hal ini berarti $t_{\text {hitung }}>t_{\text {tabel }}(6,934>1,980)$. Dengan demikian Ho yang berbunyi tidak terdapat perbedaan hasil belajar IPS antara siswa yang mengikuti pembelajaran dengan model assure bernuansa lingkungan berbantuan media audiovisual dengan siswa yang mengikuti pembelajaran dengan pendekatan konvensional pada siswa dengan minat outdoor tinggi, "ditolak". Dengan demikian dapat disimpulkan bahwa terdapat perbedaan hasil belajar IPS antara siswa yang mengikuti pembelajaran dengan model assure bernuansa lingkungan berbantuan media audiovisual dengan siswa yang mengikuti pembelajaran dengan pendekatan konvensional pada siswa dengan minat outdoor tinggi.

Temuan penelitian ini didukung oleh penelitian Purwono, Sri Yutmini dan Sri Anitah (2014) yang menyatakan hasil belajar siswa meningkat setelah guru menggunakan media Audiovisual. Menurut Ngalimun (2016) minat menjadi modal utama bagi siswa untuk meningkatkan hasil belajar, hasil belajar siswa sangat bergantung pada model yang digunakan guru dan minat belajar siswa tersebut. Model pembelajaran Assure mengahadirkan suasana belajar yang bersifat student centre. Siswa menjadi aktif dalam belajar. Seluruh indra siswa dilibatkan secara maksimal sehingga lebih mudah memahami pelajaran. Selain itu pembelajaran Assure juga menekankan pada keterlibatan lingkungan dalam proses pembelajaran. Hal ini berkaitan langsung dengan minat outdoor, yang mana minat outdoor merupakan ketertarikan siswa terhadapat lingkungan di sekitarnya. Minat outdoor yang tinggi sangat membantu siswa dalam memahami pelajaran IPS. Sedangkan, dalam pembelajaran yang menggunakan model pembelajaran Assure, guru memiliki peranan yang sangat penting. Hal ini dikarenakan guru mempunyai tanggung jawab yang besar terhadap penstrukturan materi. Pembelajaran yang berpusat pada guru, akan berimplikasi terhadap rendahnya hasil belajar siswa. Dengan demikian, dapat disimpulkan bahwa untuk siswa yang memiliki minat outdoor tinggi, dengan mengikuti pelajaran dengan model Assure lebih baik daripada siswa yang mengikuti pelajaran dengan pembelajaran konvensional.

Perbedaan Hasil Belajar IPS Antara Siswa Yang Mengikuti Pembelajaran Dengan Model Assure Bernuansa Lingkungan Berbantuan Media Audiovisual Dengan Siswa Yang Mengikuti Pembelajaran Dengan Pendekatan Konvensional Pada Siswa Dengan Minat Outdoor Rendah. Berdasarkan hasil temuan dalam penelitian ini, perhitungan didapat thitung sebesar 1,561 sedangkan $t_{\text {tabel }}$ pada taraf signifikansi $\alpha=$ 0,05 sebesar 1,980 . Hal ini berarti thitung $<t_{\text {tabel }}(1,561<1,980)$. Dengan demikian Ho yang berbunyi tidak terdapat perbedaan hasil belajar IPS antara siswa yang mengikuti pembelajaran dengan model assure bernuansa lingkungan berbantuan media audiovisual dengan siswa yang mengikuti pembelajaran dengan pendekatan konvensional pada siswa dengan minat outdoor rendah, “diterima”. Dengan demikian dapat disimpulkan bahwa tidak terdapat perbedaan hasil belajar IPS antara siswa yang mengikuti pembelajaran dengan model assure bernuansa lingkungan berbantuan media audiovisual dengan siswa yang mengikuti pembelajaran dengan pendekatan konvensional pada siswa dengan minat outdoor rendah. Temuan penelitian ini didukung oleh penelitian Adnyana (2017) yang menyatakan bahwa siswa yang memiliki minat outdoor rendah, tidak terdapat perbedaan hasil belajar antara siswa yang mengikuti pembelajaran dengan model pembelajaran Kuantum dan siswa yang mengikuti pembelajaran langsung.

Penerapan model pembelajaran Assure, pada siswa yang memiliki minat outdoor rendah akan membuat siswa menjadi tertekan dalam mengikuti pelajaran karena pada model pembelajaran Assure, siswa dituntut untuk selalu aktif dalam mengkonstruk pengalaman belajarnya. Siswa yang memiliki minat outdoor rendah yang cenderung pasif akan lebih suka mengikuti langkah-langkah belajar yang teratur dan jelas karena mereka umumnya menerima materi pelajaran cenderung apa adanya. Mereka lebih terbiasa dengan belajar menghafal dan pembelajaran tanpa tekanan. Sehingga apabila diajarkan dengan model pembelajaran yang menggunakan pendekatan konstruktivisme akan menyulitkan bagi mereka (Pribadi, 2011). 
Sementara itu, apabila siswa yang memiliki minat outdoor rendah diberikan pembelajaran konvensional yaitu pembelajaran yang berpusat pada guru, yang pembelajarannya tanpa ada tekanan membuat mereka merasa lebih senang dan tenang dalam mengikuti proses pembelajaran karena mereka terbiasa dengan proses pembelajaran terbimbing. Jika siswa sudah merasa senang dengan apa yang mereka lakukan maka ini akan memicu mereka untuk berprestasi sehingga pembelajaran konvensional lebih cocok diberikan kepada siswa yang memiliki minat outdoor rendah. Berdasarkan paparan di atas, tampak bahwa setiap model pembelajaran memiliki keunggulan dan kelemahan, tergantung dari tingkat minat outdoor siswa. Siswa yang memiliki minat outdoor tinggi lebih baik diberikan pelajaran dengan menggunakan model pembelajaran Assure sementara siswa yang memiliki minat outdoor rendah hendaknya diberikan pelajaran dengan menggunakan model pembelajaran konvensional. Hal ini selajan dengna penelitian yang dilakukan oleh Jayanti (2014) yang menyatakan bahwa ada perbedaan yang signifikan antara hasil belajar siswa yang dibelajarkan dengan model pembelajaran ASSURE berbantuan media audiovisual dengan siswa yang dibelajarkan dengan pembelajaran konvensional berbantuan media audiovisual.

\section{Simpulan dan Saran}

Berdasarkan temuan di atas, dapat disimpulkan bahwa model pembelajaran Assure bernuansa lingkungan berbantuan media audiovisual ditinjau dari minat outdoor memberikan pengaruh yang signifikan terhadap hasil belajar IPS pada siswa kelas V Sekolah Dasar di Gugus I Kecamatan Lombok Timur.

Berdasarkan temuan-temuan dan simpulan yang telah dikemukakan di atas, adapun saran yang dapat diajukan dalam penelitian ini adalah sebagai berikut. (1)Penelitian ini menunjukkan bahwa hasil belajar IPS siswa yang diajar dengan model Assure bernuansa lingkungan berbantuan media audiovisual lebih baik daripada hasil belajar IPS siswa yang diajar dengan pembelajaran konvensional. Untuk itu, model Assure bernuansa lingkungan berbantuan media audiovisual perlu dikenalkan dan dikembangkan lebih lanjut kepada para guru, siswa dan praktisi pendidikan lainnya sebagai salah satu aternatif pembelajaran. Proses pengenalan dan pengembangan model Assure bernuansa lingkungan berbantuan media audiovisual dapat dilakukan melalui seminar pembelajaran IPS, atau pelatihan-pelatihan pembelajaran IPS.(2) Perlu merancang LKS terstruktur untuk anak dengan minat outdoor rendah dan melatih anak yang memiliki minat outdoor rendah agar dapat mendekati minat outdoor tinggi. (3)Penelitian lanjutan yang berkaitan dengan model Assure bernuansa lingkungan berbantuan media audiovisual perlu dilakukan dengan materi-materi IPS yang lain dengan melibatkan sampel yang lebih luas. Disamping itu, variabel lain seperti: intelegensi, minat, bakat, motivasi, konsep diri yang merupakan bagian yang tidak terpisahkan dari siswa perlu dikaji pengaruhnya terhadap pengembangan dan penerapan model Assure bernuansa lingkungan berbantuan media audiovisual serta dampaknya terhadap hasil belajar IPS.

\section{Daftar Rujukan}

Aptisoma. (2009). Pemanfaatan Lingkungan Sebagai Sumber Belajar.[online]. Tersedia:http://simbos,web.id/berita-pendidikan/pemanfaatan-lingkungan-sebagai-sumberbelajar/(23 Agustus 2017).

Ardiani, W, dkk. 2014. Model Brain Based Learning (BBL) Bernuansa Lingkungan Sekitar Berpengaruh Terhadap Hasil Belajar IPA Siswa Kelas V SD. Jurnal Mimbar PGSD Universitas Pendidikan Ganesha Jurusan PGSD Volume 2 Nomor 1 Tahun 2014. Terdapat pada: https://ejournal.undiksha.ac.id/index.php/JPGSD/article/view/3016_(diaskes tanggal 20 Desember 2017).

Dantes, N. 2014. Landasan Pendidikan Tinjauan dari Dimensi Makropedagogis. Singaraja: Universitas Pendidikan Ganesha Singaraja.

Dewi, S.R, dkk. 2014. Pengaruh Metode Pembelajaran Ekspresi Bebas Terhadap Hasil Belajar Seni Musik Ditinjau Dari Minat Outdoor Siswa Kelas XII SMA Negeri 1 Semarapura. Jurnal Ilmiah Pendidikan dan Pembelajaran. Program Pascasarjana Universitas Pendidikan Ganesha Volume 4 Tahun 2014. Terdapat pada: http://119.252.161.254/e-journal/index.php/jurnal ep/article/view/1148 (diaskes tanggal 19 Desember 2017). 
Jayanti, A, dkk. 2014. Pengaruh Penerapan Model Pembelajaran Assure Berbantuan Media Audiovisual Terhadap Hasil Belajar PKn Siswa Kelas V SD Gugus Iv Kediri, Tabanan. Jurnal Mimbar PGSD Universitas Pendidikan Ganesha Jurusan PGSD Volume 2 Nomor 1 Tahun 2014. Terdapat pada: https://ejournal.undiksha.ac.id/index.php/JJPGSD/article/viewFile/1927/1676 (diaskes tanggal 5 Januari 2018).

Likhah, Anarida Dyah Nur ,A. Dakir, Noer Hidayah. 2014. Pengaruh Penerapan Model Pembelajaran Assure Terhadap Hasil Belajar IPS. Jurnal Didaktika Dwija Indria (SOLO) Volume 2 Nomor 2.

Pribadi, B. 2011. Model ASSURE untuk Mendesain Pembelajaran Sukses. Jakarta: Dian Rakyat.

Rusman. 2011. Model-model Pembelajaran Mengembangkan Profesionalisme Guru. Jakarta: Raja Grafindo Persada.

Sari, I Gusti Ayu Martha, Siti Zulaikha, I Md. Suara. 2014. Pengaruh Model Pembelajaran Assure Berbasis Concept Mapping Terhadap Hasil Belajar Ips Siswa Kelas V Sd Gugus Letkol Wisnu Denpasar Utara. Jurnal Mimbar PGSD Universitas Pendidikan Ganesha Jurusan PGSD Vol 2 No 1.

Utomo, A.P dan Poedjiastoeti. 2014. Pengembangan Media Audio-Visual Sel Volta Dan Sel Elektrolisis Pada Materi Redoks Di SMA Development Of Visual Auditory Media Voltaic Cells And Electrolysis Cells Subject Redox In Senior High School. Jurnal UNESA Journal of Chemical Education Volume 3 Nomor 3 Tahun 2014. Terdapat pada: http://jurnalmahasiswa.unesa.ac.id/index.php/journal-ofchemical-education/article/view/9769 (diaskes tanggal 7 Januari 2018).

Wibowo, Ahmad Sri, St.Y. Slamet, Dwiji Astuti. 2014. Pengaruh Model Pembelajaran Assure Terhadap Kemampuan Menghitung Luas Bangun Datar Bagi Siswa Kelas V SD. Jurnal Didaktika Dwija Indria (SOLO) Vol 2 No 5. 